\title{
Canvas model of the mining regions' industrial ecosystem based on a circular economy
}

\author{
Oleksandr Amosha ${ }^{1}$, Danylo Cherevatskyi ${ }^{1}$, Oleksandr Lyakh $^{1, *}$, Myroslava Soldak ${ }^{1}$, and \\ Yuliya Zaloznova ${ }^{1}$ \\ ${ }^{1}$ Institute of Industrial Economics of the National Academy of Sciences of Ukraine, Maria Kapnist \\ Street, 2, 03057 Kyiv, Ukraine
}

\begin{abstract}
In order to elaborate the concept of an industrial ecosystem for circular economy for old industrial coal mining regions in Ukraine, we apply Corrine Beaumont's Lean Tribe Canvas model. The concept is based on combination of several approaches, including smart shrinking, urban mines, smart specialisation. The main idea of this concept is to organize an integrated industrial ecosystem for processing of accumulated waste of coal mining and enrichment for decades using innovative technologies for retrieving energy and other products during waste processing, as well as restructuring abandoned housing and unused industrial infrastructure. This should slow down decline of mining settlements, allow to reducing effects of anthropogenic impact on the environment in these regions, as well as mitigate social tension in the places where closed coal mines and related businesses were located. The mining town of Bílytske in Donetsk oblast was chosen as an example to assess technical, social and economic feasibility of a project based on the stated concept.
\end{abstract}

\section{Introduction}

Coal mining regions crises started when "coal era" came to an end in the second part of the XX century and got significantly worse after adoption of global course of technological, economic and social transformation in accordance with the paradigm of sustainable development. It is impossible to achieve sustainable development aims under the conditions of current scales of human production activity without constant interaction of industrial and natural ecosystems, which regulation should depend on the level at which economic processes take place: national, regional or local.

Coal-mining headframe ruins, mine drainage waters that come into surface, methane emissions, burning tailings - is a reality in post-mining style. Of course, it is not similar to European reclaimed territories, which were cleaned to condition "from black to green field". However, even the United Kingdom, which has shown one of the most successful examples of coal industry restructuring, still have abandoned poor territories located far away from megacities. Despite global nature of crises manifestation of old industrial mining regions, they differ significantly. Thus, conglomeration in West Germany, which was called "Ruhr-Stadt", represents a number of settlements interspersed with production

\footnotetext{
* Corresponding author: lyakh $\mathrm{O} @$ nas.gov.ua
} 
sites of coal and metallurgical enterprises with residential density 1,17 thousand people /square $\mathrm{km}$, that in some urban areas reached 5 thousand people /square $\mathrm{km}$. Meanwhile, in Ukraine there is Bilytske City, which grew up around the mine with same-name in Dobropil region, which has population density 4.95 thousand people / sq. km, while population density of Dobropil region is only 17 people / sq. $\mathrm{km}$.

In the territory of Donetsk and Luhansk oblasts controlled by the government of Ukraine, there are 65 towns and villages for which coal enterprise is the only place of residents' employment.

Coal mining closure requires alternatives to existing business models, for example, industrial ecosystems that are set up to recycle coal waste. These existing networks of interconnected various enterprises and institutions, which have more or less intensive metabolism and energy with greater or lesser impact on the environment, are similar to biological ecosystems $[1 ; 2]$.

One-industry specialization causes problems for mining cities around the world. One or two primary economic sectors affect city budget revenue, residents' employment, ensure functioning of social and other critical public infrastructure. Therefore, loss of activity traditional for this area is often followed by cities and towns depopulation - phenomenon of shrinking cities $[3 ; 4]$. Although the main depopulation indicator is shrinking population, the interpretation of urban shrinking is more complex, as it manifests itself in many other forms, such as abandoned vacant housing, idle plots of cities' land or economic problems [5]. Decrease in population has a negative impact on a local community, its social cohesion, while increasing social inequality and polarization, reducing attractiveness of life in some urban areas.

Studying impact of different configurations of regional innovation systems on old industrial regions ability to change their development path, Arne Isaksen and Michaela Trippl identified samples of two types of these systems: "thick" and "thin" [6]. "Thick" regional innovation systems are mainly located in urban areas and include higher education institutions, research centers and a powerful and high-tech industrial sector. Regions that have such innovative systems are less easily affected and dependent on path of their past development. While "thin" regional innovation systems have an incomplete set of these elements, and are more dependent on the past path of local economy development. Similar to this approach, industrial ecosystems can also be divided into two types. "Thick" ecosystems include economic entities that use modern "smart" and environmentally friendly technologies, digitalization opportunities for further development of green economy by increasing resource efficiency of production, while relatively connected with them powerful innovation systems allow local industrial sectors to modernize paths development of old industrial regions or create radically new ones paths. "Thin" industrial ecosystems, which are common to regions of Ukraine dependent on coal and metallurgical industries, have a relatively low technological level of industrial complex and are actually deprived of production capacity, human resources and necessary infrastructure that allow them to evolve institutions, organizational routines, economic culture of chain participants to obtain costs for transferring to higher technological level. Low level of R\&D costs and necessity to import technologies preserves further technological underrunning of "thin" industrial ecosystems, causing their path dependence, which updating might be possible only within existing technocenosis and corresponding industrial structure.

The purpose of the paper is to outlines theoretical principles and practical aspects for the formation of effective model of industrial ecosystem for sustainable development of coalmining regions after the cessation of intensive coal extracting in their territories. This is determining the logic of the study, the object of which is the process of transforming the "thin" industrial ecosystems of old industrial mining regions into ones built on the basis of circular economy. 


\section{Methodology}

The study is grounded on the approach implying formation of territorial production systems on the principles of circular economy and methodology for developing regional smart specialisation strategies. Suggested earlier by the authors implementing the concept of circular smart specialisation of old industrial mining regions based on active processing of accumulated over decades coal enrichment waste [7] requires systematic generalization. To reveal possibilities for such industrial ecosystem development, Lean Canvas technique developed by Maurya Ash was used [8], as well as its modification (Lean Tribe Canvas) offered by Corrine Beaumont [9].

Lean Tribe Canvas model includes eight key element: 1) "Tribe Troubles" (Problems that the tribe has faced); 2) "Your Solutions" (Tribe's problem solving); 3) "Unique Value Proposition"; 4) "Tribe Channels" (Channels of promotion inside a tribe), 5) "Tribe Track" (Key metrics), 6) "Your Defence" (Competitive advantage), 7) "Tribe Offering" (Income flows) i 8) "Tribe Costs" (Costs structure).

It is reasonable to consider local community as a tribe in the context of old industrial mining regions. Since a single local community is unlikely to be able to solve the problem of survival through waste recycling, more attractive alternative is joining funds of several communities to build a recycling plant, primarily to generate electricity and building materials.

Dobropilsky, Selydivsky, Pokrovsky regions of Donetsk oblast and the area of Central coal preparation plant "Chervonogradskaya" in Lviv-Volyn basin are practicable to locate utilization centers for coal enrichment waste that ground conditions for conjuncture of "tribes" forming.

In industrial ecosystems, roles of enterprises can be defined in the same way as in biological ecosystems according to functional purpose and trophic levels: generators or producers, consumers, scavengers and decomposers. Main producers represent those industries that provide raw materials to other industries. Industries that use raw materials from producers process it into finished materials and products. Scavengers recycle and return materials (which would otherwise be wasted) back to businesses for reuse, which facilitates decomposers' work. These are companies that process production and consumption waste into materials suitable for production processes. Stimulating creation and support of various enterprises and institutions specializing in waste disposal and decomposition increases sustainability and market viability of industrial ecosystems.

\section{Results}

\section{1 "Tribes" problems}

The main problem of the "tribe" is loss of local communities" income and lack of alternative employment places for their members due to closure of traditional businesses in the region, which are coal mines and concentrators operation.

\section{2 "Tribe's" problem solving}

Solution to "tribe's" problems lies in processing accumulated coal enrichment waste, which can be converted into electricity and building materials, restructuring of production, which is not necessary anymore because of coal-mines and housing liquidation, which became unnecessary due to depopulation. The decline must be civilized, environmentally and socially balanced, i.e. the one which was called "smart-shrinking". 


\subsection{Key values}

The main purpose of deployment of the circular economy in old industrial regions of Ukraine is to provide local communities with jobs and local budgetary recharge, to increase the level of comfortable living in coal-mining towns and settlements with the help of restructuring housing and industry assets, improving the environment.

\subsection{Sales channels}

Local communities should set up enterprises in circular economy. Electricity produced by them from coal enrichment waste should be supplied to power grids in case of energy shortage (peak hours); construction materials obtained as fugitive coal enrichment waste during recycling process into electricity on a contractual basis should be transferred to agents operating in the markets of construction materials; road construction enterprises should be recipients of materials recycled from buildings and constructions; non-ferrous and ferrous metals extracted in the process of restructuring housing and industrial stock are subject to sale on relevant markets of secondary materials.

\section{5 "Key metrics"}

Component «Tribe Track» might be literally translated as "Tribal way". The content of this component, from Corrine Beaumont's point of view, includes processes of goal-setting (defining final or intermediate waypoint) and controlling goal achievement.

Limited stocks of suitable for recycling coal enrichment waste in the territory belonging to the "tribe" define possible final date of community activity: it is necessary to either find a fundamentally different type of activity to replace activity connected with waste recycling and restructuring of housing and industrial infrastructure, or to be prepared for activity cessation.

Assuming that rearguard - is lastly retreating group, effective for old industrial mining cities might be considered a policy, which falls under nature of Shrinking City, circular economy, and smart specialization, according to which community must create specialized enterprises to implement rearguard strategy for restructuring municipal economy using the funds made from waste recycling.

Exactly this type of rearguard circular economic activity of enterprises should be considered as smart specialization of the region: organizations that are constantly restructuring with wide range. Property restructuring sphere should cover not only industrial facilities, but also urban infrastructure and housing, i.e. everything that has become unnecessary and can become dangerous, while recycling can bring money to the community - you should find your urban mine - that means obtain valuables and earn money $[10 ; 11]$. Infrastructure systems, such as electricity and heating, are rich in copper, aluminum and iron. For some reason, pipes and cables remain in the ground after decommissioning or shutdown of closed production facilities. Such reserves are considered as dormant reserves with significant potential for urban mining: about $20 \%$ of total reserves of aluminum and copper. For example, in Swedish city of Norrköping, there were 230 tons of copper contained in DC power cables, which have not been used since late 1930s [12].

Accordingly, the most likely consumers of resources that will be obtained in the result of circular economy enterprises operation in old industrial mining regions should be considered powerful regional energy companies, trading companies operating in the markets of construction materials, and road construction companies. 


\subsection{Competitive advantage}

Competitive advantage of old mining regions is availability of large volumes of cheap highash coal, in reality technogenic deposit, and technologies that can ensure their processing for the benefit of urban communities.

In the territory of old industrial mining regions of Ukraine in sludge concentrators (socalled "tailings") there are about 155 million tons of coal enrichment waste. Among them, amount of materials with ash content up to $45 \%$ is not more than $2 \%$, the rest of material has ash content $45-60 \%$ (about $34 \%$ of total volume) and more than $60 \%$ (64\%). Capacity of one tailing estimates on average 2.8 million tons.

Tailings are not brownfields common to European old industrial regions, but almost technogenic high-ash coal, which not only occupy a large area, but are also dangerous for the environment. Therefore, utilization of coal tailings creates a positive effect for both economy and ecology of old mining regions.

On the territory controlled by the Government of Ukraine, there are approximately 58 million tons of coal tailings belonging to 9 factories, seven of which, with about 36 million tons of accumulated waste, are located in Donetsk oblast (Fig. 1 [13]).

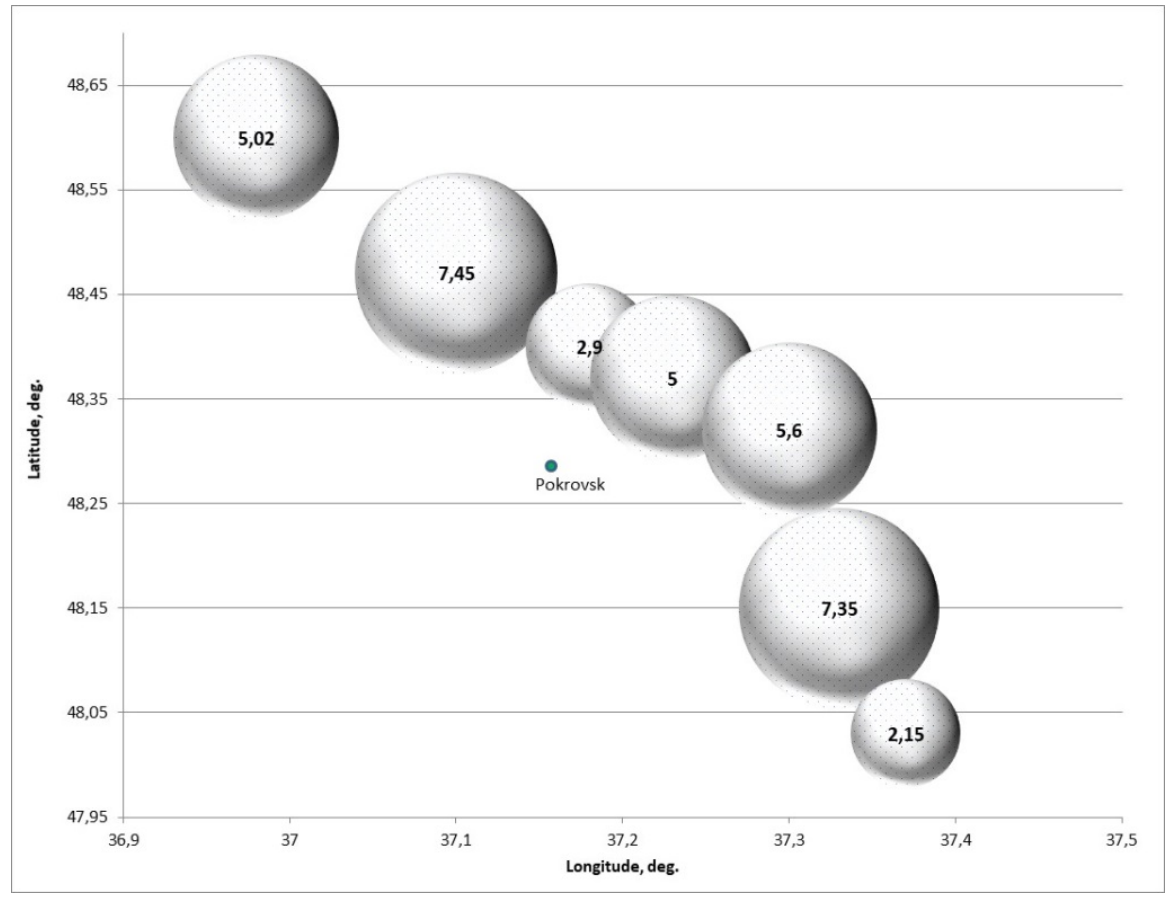

Fig. 1. Map of coal tailings (Donetsk region, million tons).

The main issue of coal tailings' utilization boils down to technology selection. Ukrainian company Innotech has suggested relatively cheap technology with a tunnel-type boiler, which allows to generate electricity and receive building materials as additional product [13].

Implementing project on coal tailings recycling at "Svyato-Varvarynska" concentrator near Pokrovsk town in Donetsk oblast was slowed down by hostilities that began in eastern Ukraine in 2014. Design capacity of power unit (45 MW) allows consumers to provide 360 million $\mathrm{kWh}$. electricity annually, and produce 67 million ceramic building blocks weighing $3 \mathrm{~kg}$ each. 
Provided technological example can be used in large coal enrichment mills. However, in the future, it is possible that standard series of technological equipment will appear, which will make the completion of small or medium capacity cantilever power plants rational and with small waste amounts also.

\subsection{Income flows and costs structure}

To assess efficiency of industrial ecosystem in mining region, it has been suggested in this paper to use annual cash flow, which is the difference between its revenues and expenditures. The system operates without losses, if its inherent annual break-even cash flow exceeds the indicators specified in the paper [13, p. 96].

According to our calculations [13, p. 178], local community of Bilytske town needs almost UAH 13 million (roughly US $\$ 0,5 \mathrm{~m}$ ) per year to simply reproduce its potential. This amount can be used to assess adequacy of annual cash flow generally generated by proposed circular economy of ecosystem. The amount is relatively small when compared, for example, with budgets of poor Polish towns [14].

\section{Discussion}

Solving a set of social, environmental and economic problems of coal-mining regions requires stimulating emergence and development of circular economy model of industrial enterprises activity, creation of a variety of garbage companies and decomposers. To solve a complex of social, environmental and economic issues of coal-mining regions, it is necessary to stimulate the emergence and development of a model of behavior of industrial enterprises based on the principles of a circular economy, the creation of many companies that function as "scavengers" and "decomposers".

This involves identifying barriers, primarily of institutional nature ones, that have been slowing down implementing these initiatives implementation and development of mechanisms that coordinate internal motivation of business representatives from industry and other sectors of national, regional and local economies, as well as other beneficiaries, especially local communities, which will receiving social and environmental benefits under implementing the concept of circular smart specialisation in on their territories.

In order to initiate and implement suggested project to create industrial ecosystem, it is necessary to involve in this process active participation not only authorities at all levels, but also non-governmental organizations, local businesses and a wide range of members of relevant communities. The most suitable for this is regional smart specialization.

In Markku Sotarauta's opinion, smart specialisation requires better understanding of modes of government's action and governance systems participation, as well as how different participants with different interests might really be joined to work together to for development of the a region [15].

Business projects in on circular economy, including those related to creation and management of waste disposal facilities, are considered being risky, which require nontraditional schemes to raise funding: crowdfunding, public-private partnerships, indirect financial support from state and regional authorities.

\section{Conclusions}

The paper offers concept of a model of industrial ecosystem for old industrial mining regions, which is able to ensure their sustainable development after cessation of intensive coal production. Functioning of such integrated industrial ecosystem will involve 
processing of accumulated waste from coal mining and enrichment for decades using innovative technologies to retrieve energy and other products during waste processing, as well as restructuring abandoned residential housing and unused industrial infrastructure.

Based on the analysis of technological options for the development of old industrial mining regions, it has been defined that their circular smart specialization can be implemented by processing coal enrichment waste into electricity and construction materials. Successful example for such a project, which experience might be extended to other local communities in mining regions, should be considered construction of $45 \mathrm{MW}$ power unit at "Svyato-Varvarynska" coal enrichment mill, powerful enough to provide not only electricity, but as well as annual production of 67 million of block wall units weighing $3 \mathrm{~kg}$ each.

It is substantiated that circular smart specialisation in old industrial mining regions should have rearguard character, i.e. provide environmentally and socially acceptable process of restructuring mining towns and settlements during their smart shrinking.

\section{References}

1. Andreoni, A. (2018). The architecture and dynamics of industrial ecosystems: diversification and innovative industrial renewal in Emilia Romagna. Camb. J. Econ., 42(6), 1-30. https://doi.org/10.1093/cje/bey037

2. Malone, S. M., Weissburg, M. J., \& Bras, B. (2018). Industrial ecosystems and food webs: an ecological-based mass flow analysis to model the progress of steel manufacturing in China. Eng. (Elsevier), 4(2), 209-217. https://doi.org/10.1016/j.eng.2018.03.008

3. Batunova, E. (2021). Urban shrinkage, aging, and economic change. In: Leal, F.W., Azul, A.M., Brandli, L., Özuyar, P.G., Wall, T. (eds.) Sustainable Cities and Communities. Encyclopedia of the UN Sustainable Development Goals. Cham: Springer. https://doi.org/10.1007/978-3-319-71061-7_102-1

4. Li, H., \& Mykhnenko, V. (2018). Urban shrinkage with Chinese characteristics. Geogr. J. 184, 4, 398-412. https://doi.org/10.1111/geoj.12266

5. Haase, A., Bontje, M., Couch, C., Marcinczak, S., Rink, D., Rumpel, P., \& Wolff, M. (2021). Factors driving the regrowth of European cities and the role of local and contextual impacts: A contrasting analysis of regrowing and shrinking cities. Cities, 108, 102942. https://doi.org/10.1016/j.cities.2020.102942

6. Isaksen, A., \& Trippl, M. (2016). Path development in different regional innovation systems: A conceptual analysis. In M. Parrilli, R. Fitjar, and A. Rodríguez-Pose (eds.) Innovation drivers and regional innovation strategies. London: Routledge, pp. 66-84. https://doi.org/10.4324/9781315671475.

7. Amosha, O., Lyakh, O., Soldak, M. and Cherevatskyi, D. (2018). Institutional determinants of implementation of the concept: Case for old industrial coal-mining regions in Ukraine. J. Eur.Econ., 17, 3 (665), 305-332. https://doi.org/10.35774/jee2018.03.305

8. Ash, M. (2012). Running lean: second edition. Iterate from plan A to a plan that works. Sebastopol, CA: O'Reilly Media Inc., $238 \mathrm{p}$. Available online: https://ziplaunchpad.sdsu.edu/_resources/files/Running_Lean_Second_Edition.pdf

9. JaysLondonXperience (2014). Think Different: Choosing the Best Persona for your Target Consumer Group! https://jayslondonxperience.wordpress.com/page/2

10. Medkova, K., \& Fifield, B. (2016). Urban mines - the mines of circular economy. In Aalto, A., Montonen, L. (eds.). Smart Cities in Smart Regions 2016: Conference Proceedings, 64-73 (Lahti, Finland, 10-12 May, 2016). Available online: https://core.ac.uk/download/pdf/80993515.pdf 
11. Holland, J., \& Angelis-Dimakis, A. (2017). Assessing the urban mining potential in the City of Huddersfield, UK. In 15th International Conference on Environmental Science and Technology. (Rhodes, Greece, 31 August - 2 September, 2017). https://cest.gnest.org/sites/default/files/presentation_file_list/cest2017_00908_oral_pape r.pdf

12. Wallsten, B., Carlsson, A., Frändegård, P., Krook, J., \& Svanström, S. (2013). To prospect an urban mine-assessing the metal recovery potential of infrastructure "cold spots" in Norrköping, Sweden. J. Clean. Prod. 55, 103-111. https://doi.org/10.1016/j.jclepro.2012.05.041

13. Amosha, O. (ed.), Cherevatskyi, D., Soldak, M., Lyakh, O., Zaloznova, Yu. et al. (2020). Circular of old industrial mining regions of Ukraine. Kyiv: IEP NAS of Ukraine.

https://iie.org.ua/monografiyi/cirkuljarna-smart-specializacijastaropromislovih-shahtarskih-regioniv-ukraini

14. Runge, A., Runge, J., Kantor-Pietraga, I., \& Krzysztofik, R. (2020). Does urban shrinkage require urban policy? The case of a post-industrial region in Poland. Reg. Stud., Reg. Sci. 7, 1, 476-494. https://doi.org/10.1080/21681376.2020.1831947

15. Sotarauta, M., \& Suvinen, N. (2019). Place leadership and the challenge of transformation: policy platforms and innovation ecosystems in promotion of green growth. European Planning Studies, 27, 9, 1748-1767. https://doi.org/10.1080/09654313.2019.1634006 